\title{
Health Risk from the Consumption of Freshwater Prawn and Crab Exposed to Heavy Metals in a Tropical River, Southern Nigeria
}

\section{Abstract}

The objectives of this study were to investigate the impact of heavy metals in two freshwater decapods and to evaluate the toxicity and human health risks through the consumption of these freshwater decapods. Nine (9) heavy metals were investigated in accordance with standard procedures and analyzed monthly from March 2015-August 2016 in the studied decapods. The results of the heavy metal concentrations in the prawn and crab varied in this rank; $\mathrm{Fe}>\mathrm{Zn}>\mathrm{Mn}>\mathrm{Cu}>\mathrm{Pb}>$ $\mathrm{Cd}>\mathrm{Cr}>\mathrm{Ni}=\mathrm{V}$ for prawn and $\mathrm{Zn}>\mathrm{Fe}>\mathrm{Mn}>\mathrm{Cu}>\mathrm{Pb}>\mathrm{Cd}>\mathrm{Cr}>\mathrm{Ni}=\mathrm{V}$ for shrimp. The results of the human health risk assessments revealed high values of Iron (Fe) and Zinc ( $\mathrm{Zn}$ ) for the target hazard quotient (THQ) and estimated daily intake (EDI) as well as high values of Iron (Fe), Zinc (Zn), and Manganese (Mn) for the health risk impact (HRI). All most all the values obtained were above allowable limits in prawn and crab respectively. Strict environmental laws should be reinforced and compliance should be adhered to in order to protect humans from consuming freshwater decapods sourced from various points.

Keywords: Decapods; Health risk; Trace metals; Contamination; Ossiomo river; Pollution indices

Received: October 15, 2018; Accepted: October 24, 2018; Published: November 01, 2018

\section{Introduction}

In recent times, the hunts for freshwater decapods for man's consumption have increased. However, the ecospheres of these freshwater species have been altered in many forms; through some hydrological and ecosystem amplification processes viz; underground pollutant seepage, bioturbation, movement of pollutants into aquatic bodies via surface water and sediment inundation and anthropogenic processes.

Man has used many heavy metals for centuries, but only in the last few decades have the possible effects of heavy metals in the environment and on human health been studied [1-5]. Heavy metals are introduced into the environment (e.g. Aquatic systems) as a result of weathering of rocks and soils [6], thus the highest contents of heavy metals are in metal-rich areas, such as ore rich deposits.

Due to the non-biodegradable and persistent nature, heavy metals accumulate in vital organs in the human body, such as the kidneys, bones, and liver and are associated with numerous serious Health disorders [7]. Individual metals exhibit specific

\section{Osikemekha Anthony Anani ${ }^{1 *}$ and John Ovie Olomukoro²}

1 Department of Biological Science, Edo University Iyamho, Edo State, Nigeria

2 Department of Animal and Environmental Biology, University of Benin, Benin City, Pmb 1154, Nigeria

\section{*Corresponding author: \\ Osikemekha Anthony Anani \\ ” cybert2004@gmail.com; osikemekha.anani@edouniversity.edu.ng}

Department of Biological Science, Edo University Iyamho, Edo State, Nigeria.

Citation: Anani OA, Olomukoro JO (2018) Health Risk from the Consumption of Freshwater Prawn and Crab Exposed to Heavy Metals in a Tropical River, Southern Nigeria. J Heavy Met Toxicity Dis Vol.3 No.2:5 
regulatory controls. The risk characterization compares the hazard/toxicity of exposure and determines the likely for and extent of risk to an exposed individual or population nature, including complementary ambiguity [14].

To the best of our knowledge, this is the first health risk assessment on freshwater prawn and crabs sourced from this region. The obtained information may provide a better understanding of environmental risks of heavy metals in freshwater biotas.

On this note, the objective of this study is to assess some selected heavy metals in two freshwater decapods and evaluate the probable health risks associated with their consumption by humans.

\section{Materials and Methods}

\section{Study site}

The study was conducted at about $5.1 \mathrm{~km}$ stretch of the Ossiomo River (Ologbo axis), Benin City situated in the South West of Nigeria, in the following geographical locations; Latitude $6^{\circ} 03^{\prime} .1^{\prime \prime}$ $\mathrm{N}$ - Longitude $5^{\circ} 40^{\prime} .3^{\prime \prime} \mathrm{E}$ (Figure 1).

The river is mostly fed by surface runoffs from neighbouring communities of Okuku, Ugbenu, Ovade, Asaboro and Imasabor respectively through adjoining streams and rivers. The tempo of rainfall occurs in combination with the movement of the Southern-West rainy season wind across the Atlantic Ocean and the programming of this movement varies from year to year [15]. There are two separate annual seasons associated with this region: the rainy season, which begins in early March and ends in late November, and the dry season which starts from November and ends in March. The average rainfall for 2015 and 2016, ranged from 160.7-708.5 $\mathrm{mm}$ with the lowest recorded in the month of May $2015(158.4 \mathrm{~mm})$ and the peak recorded in the month of September 2015 (708.5 mm).

The principal aquatic macrophytes here included; Azolla africana (Mosquito Fern or Water Velvet), Nymphaea lotus (red and blue water lily), Cyperus alopecuroides (Umbrella palm), Salvinia nymphellula (Water Moss), Echinochloa pyramidalis (Antelope grass or Barnyard grass or Cockspur grass) and Pistia stratiotes (water cabbage, Nile cabbage, or shell flower).

Human activities within and around this river included; logging, fishing, boating, watercraft maintenance, discharging of cassava effluent products, sawmilling, transportation, laundering, bathing and swimming, crude oil exploration and processing.

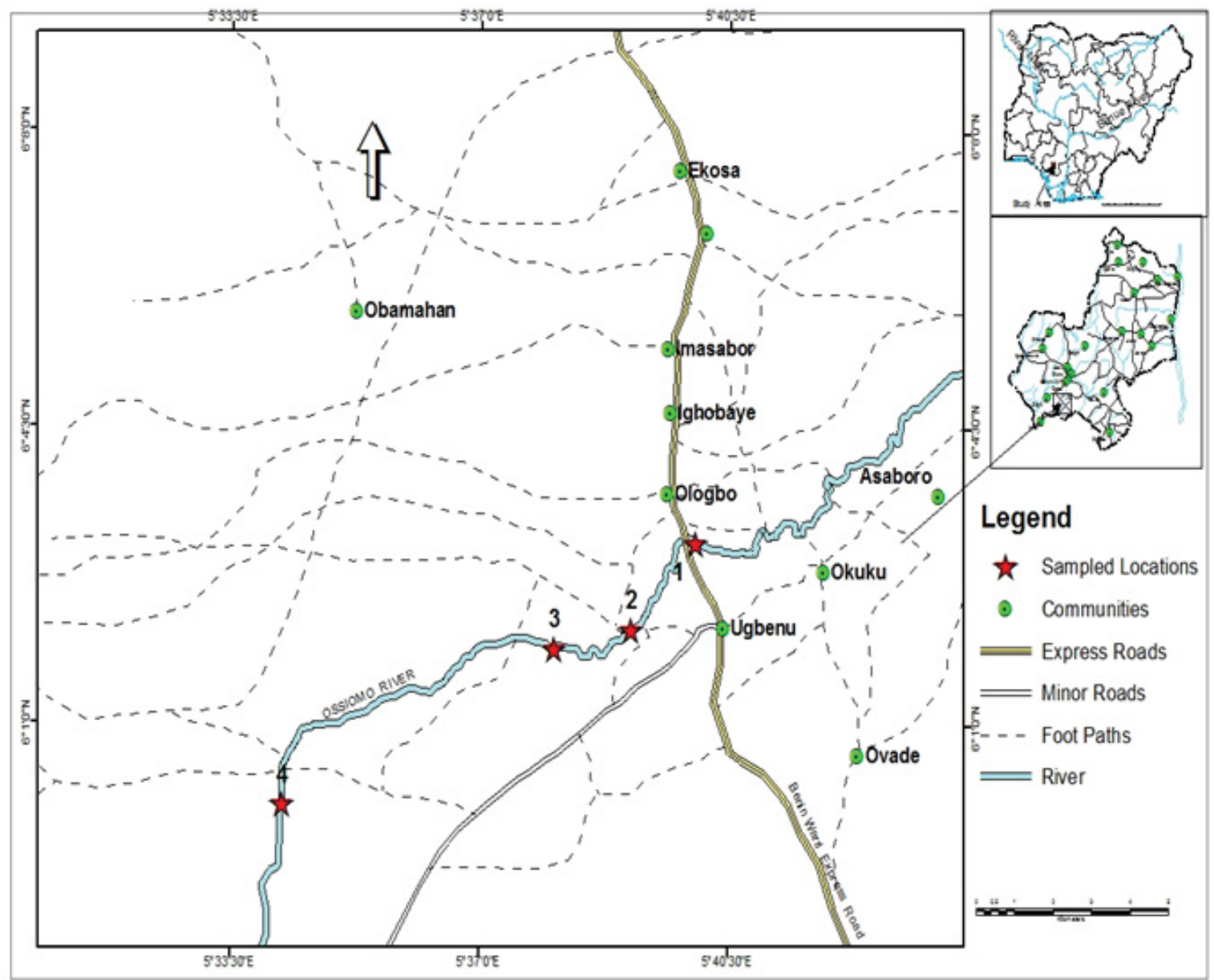

Figure 1 Map of the study area and sampling stations. 


\section{Field sampling and techniques}

The sampling period spanned from March 2015 to August 2016. Samples were collected from four designated stations on each sampling day between the hours of 09.00 and 12.00 hours. Each time, sampling began at station 1 and terminated at station 4 . Specimens of Macrobrachium rosenbergii (freshwater prawn) and Sudanonautes africanus (freshwater crab) were collected at low tide regime at the river bank using woven cylindrical traps with a non-return valve. They were collected from a couple of fishermen in order to assure regularity in fishing methods. The samples were put in pre-cleaned black polythene bags and preserved in an ice chest at $4^{\circ} \mathrm{C}$ and transferred immediately to the laboratory for analysis [16].

\section{Sample preparation and metal analysis}

In the laboratory, prior to drying in an oven at $105^{\circ} \mathrm{C}$, weights of Macrobrachium rosenbergii and Sudanonautes africanus samples were measured with the aid of electronic balance (Rs 9,000/Unit, Sigma MS Tablet dissolution apparatus, Sigma 135, India) according to the methods of Enuneku et al. [16]. Two grams of a dried homogenized sample of each tissue were digested using a XT-9912 model microwave system (Xintuo, China) in $15 \mathrm{ml}$ hydrochloric acid, $5 \mathrm{ml}$ nitric acid, and $5 \mathrm{ml}$ Perchloric acid (3:1:1) solution and heated in a digester until brown fumes were expelled, tissues dissolved completely and a colorless solution obtained. The flask and its contents were allowed to cool and thereafter the digested sample was made up to $50 \mathrm{ml}$ of distilled water [17]. Prawn and Crab samples were analysed for Fe (Iron), Mn (Manganese), Zn (Zinc), Cu (Copper), Cr (Chromium), Cd (Cadmium), Ni (Nickel), Pb (Lead), and V (Vanadium) using Atomic Absorption spectrophotometer (SOLAAR 969AA UNICAM, Spectronic Unicam, Cambridge, UK).

\section{Quality control analysis}

The Atomic Absorption Spectrophotometer was first calibrated using certified reference standard (SRM 1570) of the National Institute of Standards and Technology for the respective heavy metals to obtain calibration curve with the equation $r^{2}=99.7$. Reagent blank was run at intervals of every five sample analysis to eliminate equipment drift [16]. All samples were analyzed in triplicates for reproducibility accurate checks and precision.

\section{Human health risk assessment}

Target Hazard Quotient (THQ): The THQ method was adopted from the United States EPA Region III Risk based concentration table [18] as modified by Chien et al. [19]. The dosage estimation was calculated as:

$\mathrm{THQ}=\frac{E f r \times E D t o t \times F I R \times C \times 10^{-3}}{R f D o \times B W a \times A T n}$

Where EFr is exposure frequency (365 days/year); EDtot is the exposure duration 52 years, average lifetime); FIR is the food ingestion rate ( $5 \mathrm{~g} /$ day) as collected using questioners; $\mathrm{C}$ is the heavy metal concentration in crab/prawn $(\mathrm{mg} / \mathrm{kg})$; RfDo is oral reference dose $(\mathrm{mg} / \mathrm{kg} /$ day) and ATn is average exposure time for non-carcinogens in days. The following reference doses were used: $\mathrm{Cr}=1.5, \mathrm{Fe}=0.001, \mathrm{Zn}=0.0006(\mathrm{mg} / \mathrm{kg} /$ day $), \mathrm{Mn}=0.001$ (mg/kg/day), $\mathrm{Cu}=0.001$ (mg/kg/day), $\mathrm{Ni}=2.0 \times 10^{-2}(\mathrm{mg} / \mathrm{kg} /$ day $)$, $\mathrm{Pb}=4.0 \times 10^{-3}\left(\mathrm{mg} / \mathrm{kg} /\right.$ day) and $\mathrm{Cd}=1.0 \times 10^{-3}(\mathrm{mg} / \mathrm{kg} /$ day $)$. BWa is the average adult body weight $(70 \mathrm{~kg})$ and ATn is the average exposure time for non-carcinogens (365 days/year $\times$ number of exposure years assuming 52 years). Since exposure to two or more pollutants may result in additive and/or interactive effects, total THQs in this study was treated as the arithmetic sum of the individual metal THQ values, derived by the method of [20].

Estimated Daily Intake (EDI): The estimated daily intake (EDI) method by Ali and Hau, [20] and Saha and Zeman [21] for estimating heavy metal concentration in foodstuffs were employed in this study. The estimated daily intake (EDI) of each heavy metal in this exposure pathway was determined by the equation:

$\mathrm{EDI}=\frac{E f \times E D \times C F \times C M}{W A B \times T A}$

Where EF is the exposure frequency (365 days/year); ED is the exposure duration, equivalent to an average lifetime (52 years for Nigeria population); FIR is the fresh food ingestion rate $(\mathrm{kg} /$ person/day), which was considered to be 5 for both decapods [20]; Cf is the conversion factor (0.208) for fresh weight (FW) to dry weight (Dw). Cm is the heavy metal concentration in foodstuffs (mg/kg Dw.); WAB is the average body weight (bw) (average adult body weight was considered to be $70 \mathrm{~kg}$ ); and TA is the average exposure time for non-carcinogens (equal to $E F \times E D$ ).

Health Risk Impact (HRI): The health risk impact (HRI) method as by Wang et al. was adopted for this study. Below is the equation:

$\mathrm{HRI}=\frac{E D I}{R f d}$

An HRI less than 1 means the exposed population is unlikely to experience obvious adverse effects; whereas at HRI above 1 means that there is a chance of non-carcinogenic effects, with an increasing probability as the value increases. Where reference oral doses (RfD) for $\mathrm{Cr}, \mathrm{Cu}, \mathrm{Zn}, \mathrm{Fe}, \mathrm{Ni}, \mathrm{Pb}$, and $\mathrm{Cd}$ are $1.5 \times 10^{-3}, 4.0$ $\times 10^{-2}, 3.0 \times 10^{-1}, 7.0 \times 10^{-1}, 2.0 \times 10^{-2}, 3.5 \times 10^{-3}, 1.4 \times 10^{-1}$ and 1.0 $\times 10^{-3} \mathrm{mg} / \mathrm{kg} /$ day respectively [22].

All data and charts were computed using Microsoft Excel version $2013^{\odot}$.

\section{Results}

Table 1 and Figure $\mathbf{2}$ show the rank of heavy metal concentration in prawn and shrimp. The values revealed the rank of $\mathrm{Fe}>\mathrm{Zn}>$ $\mathrm{Mn}>\mathrm{Cu}>\mathrm{Pb}>\mathrm{Cd}>\mathrm{Cr}>\mathrm{Ni}=\mathrm{V}$ for prawn and $\mathrm{Zn}>\mathrm{Fe}>\mathrm{Mn}>\mathrm{Cu}$ $>\mathrm{Pb}>\mathrm{Cd}>\mathrm{Cr}>\mathrm{Ni}=\mathrm{V}$ for shrimp.

\section{Target hazard quotients of heavy metals in prawn (Macrobrachium rosenbergii) and crab (Sudanonautes africanus)}

Table 1 showed the results of the target hazard quotients (THQs) 
Table 1 THQs of the studied heavy metals in prawn (Macrobrachium rosenbergii) and crab (Sudanonautes africanus).

\begin{tabular}{|c|c|c|c|c|c|}
\hline $\begin{array}{c}\text { Elements } \\
\text { in } \mathbf{~ m g / k g}\end{array}$ & $\begin{array}{c}\text { Mean Concentration of heavy metals in } \\
\text { prawns }\end{array}$ & $\begin{array}{c}\text { Mean Concentration of } \\
\text { heavy metals in Crabs }\end{array}$ & $\begin{array}{c}\text { THQ } \\
\text { RfDo } \\
\text { in Prawns }\end{array}$ & $\begin{array}{c}\text { THQ in } \\
\text { Crabs }\end{array}$ \\
\hline $\mathrm{Fe}$ & 134.77 & 174.02 & 0.001 & $9.63 \mathrm{E}+00$ & $1.24 \mathrm{E}+01$ \\
\hline $\mathrm{Zn}$ & 52.20 & 74.03 & 0.001 & $6.21 \mathrm{E}+00$ & $8.81 \mathrm{E}+00$ \\
\hline $\mathrm{Mn}$ & 1.69 & 3.13 & 0.001 & $1.21 \mathrm{E}-01$ & $2.24 \mathrm{E}-01$ \\
\hline $\mathrm{Cu}$ & 0.63 & 0.90 & 0.001 & $4.47 \mathrm{E}-02$ & $6.42 \mathrm{E}-02$ \\
\hline $\mathrm{Pb}$ & 0.01 & 0.03 & 0.000 & $2.37 \mathrm{E}-03$ & $4.71 \mathrm{E}-03$ \\
\hline $\mathrm{Cr}$ & 0.00 & 0.02 & 1.500 & $1.57 \mathrm{E}-07$ & $7.97 \mathrm{E}-07$ \\
\hline $\mathrm{Cd}$ & 0.01 & 0.02 & 0.001 & $9.34 \mathrm{E}-04$ & $1.19 \mathrm{E}-03$ \\
\hline $\mathrm{Ni}$ & 0.00 & 0.00 & 0.020 & $0.00 \mathrm{E}+00$ & $0.00 \mathrm{E}+00$ \\
\hline $\mathrm{V}$ & 0.00 & 0.00 & 0.010 & $0.00 \mathrm{E}+00$ & $0.00 \mathrm{E}+00$ \\
\hline
\end{tabular}

NOTE: THQ: total hazard quotient, THQs: total hazard quotients and RFDo: reference dosage

\section{Prawn Crab}

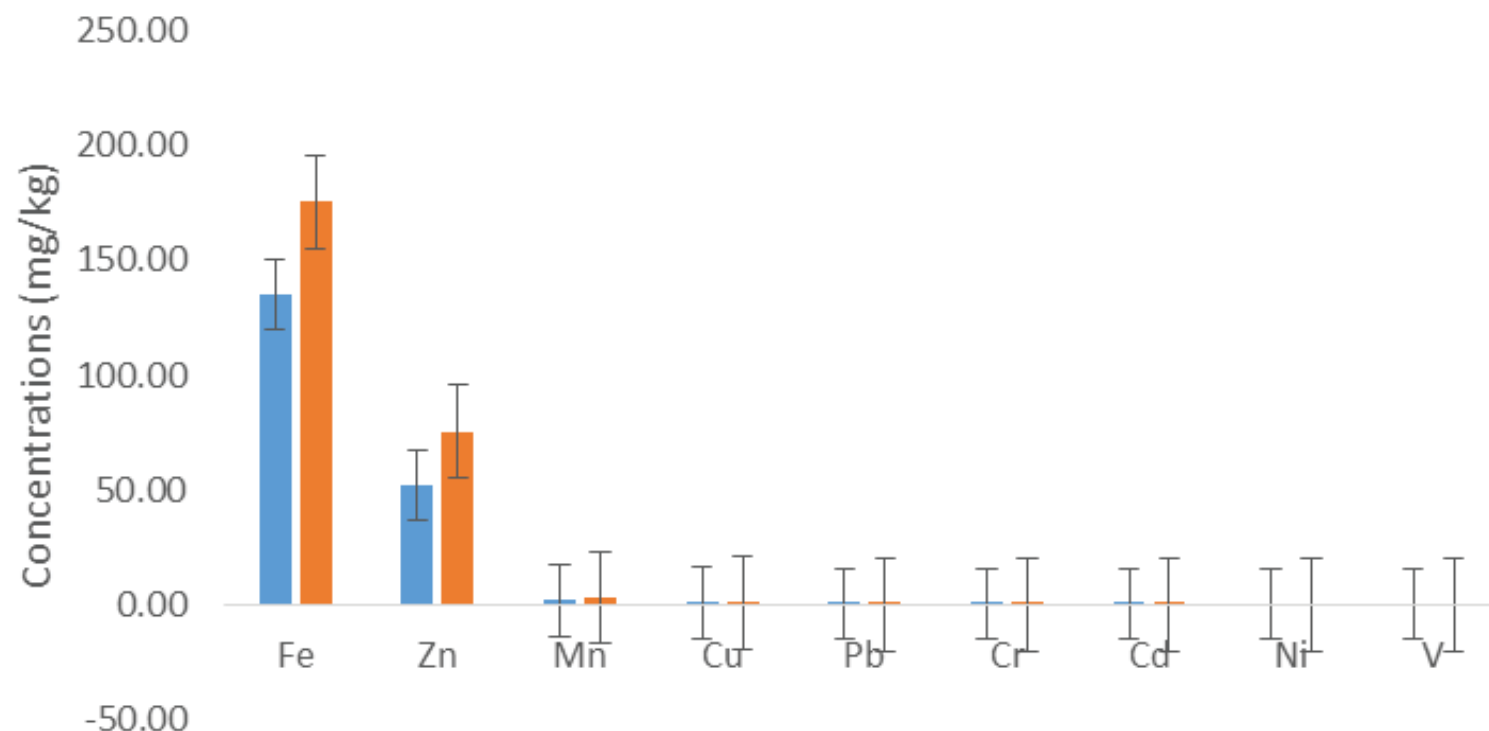

\section{Heavy metals}

Figure 2 The concentration of the heavy metals in the whole tissue of prawn and crabs sourced Ossiomo River (Mean \pm Standard error).

of prawn (Macrobrachium rosenbergii) and crab (Sudanonautes africanus). The highest THQ value for prawn was Fe with the value of $9.63 \mathrm{E}+00$ and $\mathrm{Zn}$ with a value of $8.81 \mathrm{E}+00$ for crab. The least THQ values were both $\mathrm{Ni}$ and $\mathrm{V}$ with values of 0.00 and 0.00 for prawn and crab respectively. Moreover, the Total Target Hazard Quotients (TTHQs) for both prawn and crab were 1.60E+01 and $2.15 \mathrm{E}+01$ respectively.

However, the THQ values of each metal in this current study fluctuated across the varied elements which differed by their ranks as follows: prawns $\mathrm{Fe}>\mathrm{Zn}>\mathrm{Mn}>\mathrm{Cu}>\mathrm{Pb}>\mathrm{Cd}>\mathrm{Cr}>\mathrm{Ni}=\mathrm{V}$, while crab; $\mathrm{Zn}>\mathrm{Fe}>\mathrm{Mn}>\mathrm{Cu}>\mathrm{Pb}>\mathrm{Cd}>\mathrm{Cr}>\mathrm{Ni}=\mathrm{V}$.

Figure 3 shows the median concentrations of the THQ. The median THQ concentrations of the heavy metals, are in the rank order of Fe $(9.62 \mathrm{E}+00)>\mathrm{Zn}(6.26 \mathrm{E}+00)>\mathrm{Mn}(9.27 \mathrm{E}-01)$ for prawn and $\mathrm{Fe}(1.21 \mathrm{E}+01)>\mathrm{Zn}(8.13 \mathrm{E}+00)>\mathrm{Mn}$ (2.43E-01) for crab respectively.

\section{Estimated Daily Intake (EDI) of heavy metals in prawn (Macrobrachium rosenbergii) and crab (Sudanonautes africanus)}

Table 2 showed the results of the heavy metals; Fe, $\mathrm{Zn}, \mathrm{Mn}$, $\mathrm{Cu}, \mathrm{Pb}, \mathrm{Cr}, \mathrm{Cd}, \mathrm{Ni}$ and $\mathrm{V}$ in prawn and crab in terms of to their potential daily intake with the following values $0.25,0.078,0.00$, $0.02,0.05,0.002,0.19,0.00$ and $0.00 \%$ and suggested provisional tolerable daily intake (PTDI) values by the Joint Expert Committee on Food Additives (JECFA) 0.323, 0.110, 0.00, 0.003, 0.011, 0.008, $0.25,41.80$ and $0.00 \%$ in prawn and crab respectively. It was noticed that almost all the heavy metals had a low percentage of EDI to PTDI values.

The highest values of $\mathrm{Fe}$ and $\mathrm{Zn}$ were noticed in both Macrobrachium rosenbergii and Sudanonautes africanus, and this accounted for 0.25 and $0.008 \%$ for Fe and $\mathrm{Zn}$ in prawn and 0.32 and $0.11 \%$ for $\mathrm{Fe}$ and $\mathrm{Zn}$ in crab respectively. 
Health Risk Assessments (HRI) of heavy metals in prawn (Macrobrachium rosenbergii) and crab (Sudanonautes africanus)

Table 3 shows the results of the Health Risk Assessments (HRI) of the various heavy metals $(\mathrm{Fe}, \mathrm{Zn}, \mathrm{Mn}, \mathrm{Cu}, \mathrm{Pb}, \mathrm{Cr}, \mathrm{Cd}, \mathrm{Ni}$, and V). The results revealed that there were HRI values $>1$ of $\mathrm{Fe}, \mathrm{Zn}$ and $M n(2.86,2.59$ and 25.1) and (3.69, 3.67 and 46.57) in both prawn and crab respectively. $\mathrm{Mn}$ had the highest HRI for both biotas.

Table 2 EDI of the studied heavy metals in prawn (Macrobrachium rosenbergii) and crab (Sudanonautes africanus).

\begin{tabular}{|c|c|c|c|c|c|c|c|c|c|}
\hline Elements in $\mathrm{mg} / \mathrm{kg}$ & $\mathrm{Fe}$ & $\mathrm{Zn}$ & Mn & $\mathrm{Cu}$ & $\mathbf{P b}$ & $\mathrm{Cr}$ & Cd & $\mathbf{N i}$ & $\mathbf{v}$ \\
\hline \multicolumn{10}{|c|}{ Macrobrachium rosenbergii } \\
\hline Concentrations & 134.8 & 52.20 & 1.69 & 0.63 & 0.01 & 0.00 & 0.01 & 0.00 & 0.00 \\
\hline EDI & 2.00 & 0.78 & 0.03 & 0.01 & 0.00 & 0.00 & 0.00 & 0.00 & 0.00 \\
\hline \% of EDI to PTDI & 0.25 & 0.08 & 0.00 & 0.00 & 0.01 & 0.00 & 0.02 & 0.00 & 0.00 \\
\hline \multicolumn{10}{|c|}{ Sudanonautes africanus } \\
\hline Concentrations & 174.0 & 74.03 & 3.13 & 0.90 & 0.03 & 0.02 & 0.02 & 0.00 & 0.00 \\
\hline EDI & 2.6 & 1.10 & 0.05 & 0.01 & 0.000 & 0.000 & 0.000 & 0.00 & 0 \\
\hline$\%$ of EDI to PTDI & 0.32 & 0.11 & 0.00 & 0.00 & 0.01 & 0.01 & 0.02 & 41.80 & 0.00 \\
\hline PTDI \{(FAO/WHO), 1999 and 2003\} & 800 & 1000.00 & NS & 500 & 3.57 & 3 & 1 & 5 & NS \\
\hline
\end{tabular}

NOTE: Provisional tolerable daily intake (PTDI) values (in $\mathrm{mg} / \mathrm{kg}$ body wt/day) of all the metals were based on the data suggested by The Joint FAO/ WHO Expert Committee on Food Additives (JECFA) (1999 and 2003). NS means; not specified.

\section{Median}

\section{$\mathrm{Fe} \square \mathrm{Zn} \square \mathrm{Mn} \square \mathrm{Cu} \square \mathrm{Pb} \square \mathrm{Cr} \square \mathrm{Cd} \square \mathrm{Ni} \square \mathrm{V}$}

\section{$2.50 \mathrm{E}+01$ \\ $2.00 \mathrm{E}+01$ \\ $\begin{array}{ll}\stackrel{\text { ơ }}{\vdash} & 1.50 \mathrm{E}+01 \\ & 1.00 \mathrm{E}+01\end{array}$ \\ $5.00 \mathrm{E}+00$ \\ $0.00 \mathrm{E}+00$}

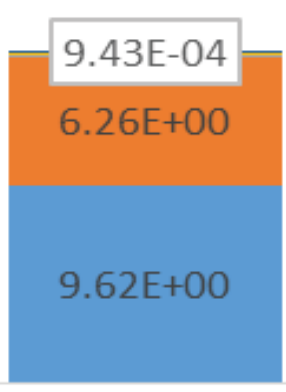

Prawn

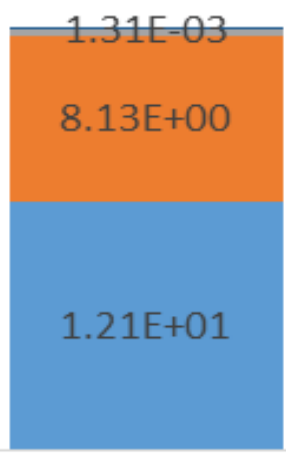

Shrimp

Species

Figure 3 THQ values based on median of documented heavy metals concentrations for Prawn and Crab sourced Ossiomo River.

Table $3 \mathrm{HRI}$ of the studied heavy metals in prawn (Macrobrachium rosenbergii) and crab (Sudanonautes africanus).

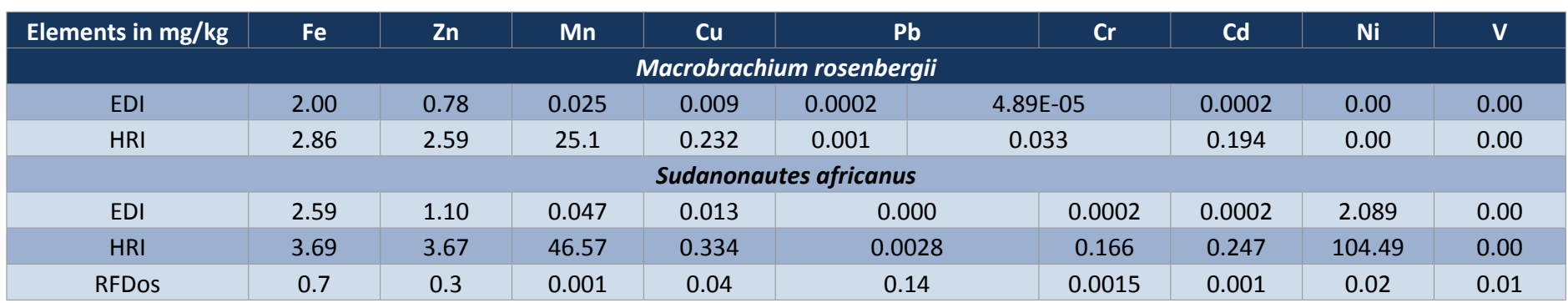

NOTE: RFDos: reference dosage, HRI: health risk assessment and EDI: estimated daily intake 


\section{Discussion}

The overall mean of heavy metals concentration in the prawn and shrimp of this study were similar to the rank of heavy metals obtained by Yilmaz and Yilmaz, Movahed et al. and Ehsani and Roomiani [23-25].

The findings of THQ in this study clearly indicated that people will experience major health risk from the consumption of accumulated concentration of $\mathrm{Fe}, \mathrm{Zn}$ and $\mathrm{Mn}$ metals from Macrobrachium rosenbergii (prawn) and Sudanonautes africanus (crab) sourced from points of collection. This is similar to the works of Storelli, Li et al., Bogdanovic et al. [26-28].

Total target hazard quotient (TTHQ) values above 1 shows that the intake of heavy metals by consuming these decapods represents a probable hazard. The TTHQ for the heavy metal intake from the decapods tested were above the threshold level (THI < 1) suggested by USEPA, (2011) and Li et al. [29]. However, TTHQ is not a measurable approximation of the likelihood of an exposed population suffering an adverse health effect [30]. The values obtained in this current study can indicate probable noncarcinogenic health risk from ingestion of all the heavy metal through consumption of these decapods. This is in line with the work of Li et al. [29] and Saher and Kanwal who stated that humans are often exposed to more than one pollutant and suffer combined or interactive effects. More so, based on the TTHQ median concentrations of the heavy metals in the decapods, the findings revealed strong health impact if the metals are consumed additively. This finding is similar to what was observed in the works of Adel et al. and Saher and Kanwal [31,32].

According to the data of PTDI as suggested by the Joint FAO/WHO, [33] and JECFA [34], it was noticed that almost all the heavy metals had the lowest percentage of EDI to PTDI values exempting Fe and $\mathrm{Zn}$. The highest value was noticed in Sudanonautes africanus and was within the safe limits. It was observed that EDI values were lesser than the set reference dosage. This indicates safe daily consumption of the decapods without any adverse health implications [35-39].

In general, $\mathrm{HRI}<1$ indicates that the exposed population is safe

\section{References}

1. Yi Y, Wang Z, Zhang K, Yu G, Duan X (2008) Sediment pollution and its effect on fish through food chain in the Yangtze River. Int J Sediment Res 23: 338-347.

2. Mitra A, Chowdhury R, Banerjee K (2012) Concentrations of some heavy metals in commercially important finfish and shellfish of the river Ganga. Environ Monit Assess 184: 2219-2230.

3. Mendil D, Uluözlü ÖD, Hasdemir E, Tüzen $M$, Sari $H$, et al. (2005) Determination of trace metal levels in seven fish species in lakes in Tokat, Turkey. Food Chem 90: 175-179.

4. Alkan N, Aktas M, Gedik K (2012) Comparison of metal accumulation in fish species from the south-eastern Black Sea. Bull Environ Contam Toxicol 88: 807-812.

5. Jabeen F, Chaudhry AS (2010) Monitoring trace metals in different from metals health risk while HRI $>1$ indicates the contrary $[40,41]$. The high HRI value of Mn observed in prawn and crab in this study revealed a great concern for manganese toxicity via consumption of the freshwater decapods. The population is therefore at greater risk of Mn toxicity. This was also reported by Khan et al., Tsafe et al. and USEPA IRIS [41-43]. However, the other metals were far greater than $1(\mathrm{HRI}>1)$ and above the reference dosage, this may also pose a serious threat along the food chain. Apart from background concentrations in this ecosystem, the relatively elevated levels of heavy metals recorded here are also functions of anthropogenic and farming activities situated close to this aquatic body washed down via runoffs $[44,45]$.

\section{Conclusion}

The ecological evaluation of the toxicity of heavy metals in the freshwater decapods had revealed the possible human health risk impact associated via consumption. In view of the human health risk assessments, the results indicated increased of Fe and $\mathrm{Zn}$ for THQ and EDI and increased of Fe, $\mathrm{Zn}$, and $\mathrm{Mn}$ for HRI above allowable limits in prawn and crab respectively.

The importance of employing a combination of health risk indices to elucidate pollution impacts by heavy metals has exposed the possible route of metals via aquatic biota along the food chain. Hence, stringent environmental laws should be reinforced and compliance should be adhered to in order to protect humans from consuming freshwater decapods from polluted sources.

\section{Acknowledgement}

The authors deem it fit here to appreciate and thank Mr. Ifeanyi Maxwell Ezenwa and Dr. Abdul-Rahman Dirisu respectively, of the Department of Animal and Environmental Biology, University of Benin, Benin City, Nigeria for their technical support and fair criticism. Special thanks to Macgill Engineering and Technical Services Limited (Division of Martlet Environmental Research Laboratory Limited) Benin City, Nigeria for carrying out an analytic laboratory experimental assessment of all samples collected pro Bono within the specific scope of this study with standard quality control and quality assurance measures.

tissues of Cyprinus carpio from the Indus river in Pakistan. Environ Monit Assess 170: 645-656.

6. Adeyeye El, Akinyugha NJ, Fesobi ME, Tenabe VO (1996) Determination of some metals in claris gariepinus (Cuvier and Vallencienns), Cyprinus carpio (L.) and Oreochromis niloticus (L.). In: fishes in a polyculture fresh water pond and their environments. Aquac 147: 205-214.

7. Duruibe JO, Ogwuegbu MDC, Egwurugwu JN (2007) Heavy metal pollution and human biotoxic effects. Int J Phys Sci 2: 112-118.

8. McCluggage D (1991) Heavy metal poisoning, NCS Magazine. The Bird Hospital, CO, USA.

9. European Union (2002) Heavy metals in wastes, European Commission on Environment.

10. Jaffa M, Ashraf M, Rasoal (1998) Heavy metals contents in some 
selected local fresh water fish and relevant water. Pak J Sci Ind Res 31: 189-193.

11. Gharib AG, Fatoorechain S, Ahmadinaiar (2003) A Determination of essential major trace elements in daily diets by comparative methodologies and alterations. Trace Elem Med 1: 43-53.

12. Agbozu IE, Opuene K (2007) Survey of heavy metals in the catfish (Syndontis clarias). Int J Environ Sci Technol 4: 93-97.

13. Koki IB, Bayero AS, Umar A, Yusuf S (2015) Health risk assessment of heavy metals in water, air, soil and fish. Afr J Pure Appl Chem 9: 204-210.

14. NRC (National Research Council) (1983) Risk assessment in the federal government: managing the process. National Research Council. National Academy Press, Washington, DC.

15. Afangideh Al, Francis EO, Eje El (2010) A preliminary investigation into the annual rainfall trend and pattern for selected towns in part of South-eastern Nigeria. J Sustain Dev 3: 3.

16. Enuneku AA, Ezemonye LI, Ainerua MO (2014) Human health risk assessment of metal contamination through consumption of Sesarmaangolense and Macrobrachium macrobrachion from Benin river, Nigeria. Eur Int J Sci Technol 3: 6.

17. Raghuramulu N, Madhavan NK, Kalyanasundaram S (2003) A manual of laboratory techniques. National Institute of Nutrition. Indian Council of Medical Research, Hyderabad -500007, India. Pp: 56-58.

18. US EPA (1989) Risk assessment guidance for superfund. Vol. I: Human health evaluation manual (Part A); EPA/540/1- 89/002.

19. Chien LC, Hung TC, Choang KY, Yeh CY, Meng PJ, et al. (2002) Daily intake of TBT, $\mathrm{Cu}, \mathrm{Zn}, \mathrm{Cd}$ and As for fishermen in Taiwan. Sci Total Environ 285: 177-185.

20. Ali M, Hau VTB (2001) Vegetables in Bangladesh: economic and nutritional impact of new varieties and technologies. Asian Vegetable Research and Development Centre (AVRDC) Technical Bulletin 25.

21. Saha N, Zaman MR (2012) Evaluation of possible health risks of heavy metals by consumption of foodstuffs available in the central market of Rajshahi City, Bangladesh. Environ Monit Assess 185: 3867-3878.

22. US EPA (2009) United States Environmental Protection Agency, Risk-based concentration table. Philadelphia: United States Environmental Protection Agency, Washington, DC.

23. Yilmaz AB, Yilmaz $L$ (2007) Influences of sex and seasons on levels of heavy metals in tissues of green tiger shrimp (Penaeus semisulcatus de Hann, 1844). Food Chem 101: 1664-1669.

24. Movahed A, Dehghan A, Hajihosseini R, Akbarzadeh S, Zendehboudi A, et al. (2013) Evaluation of heavy metals in the tissues of different species of shrimps collected from coastal waters of Bushehr, Persian Gulf. Iran South Med J 16: 100-109.

25. Ehsani J, Roomiani L (2015) Study bioaccumulation of heavy metals $(\mathrm{Zn}, \mathrm{Cu}, \mathrm{Cd}, \mathrm{Pb})$ in metapenaeus affinis in bahrekan, west-north of persian gulf. J Mar Sci Technol 14: 85-95.

26. Storelli MM (2008) Potential human health risks from metals $(\mathrm{Hg}$ $\mathrm{Cd}$, and $\mathrm{Pb}$ ) and polychlorinated biphenyls (PCBs) via seafood consumption estimation of target hazard quotients (THQs) and toxic equivalents (TEQs). Food Chem Toxicol 46: 2782-2788.

27. Li XY, Liu L, Wang YG, Luo GP, Chen X, et al. (2013) Heavy metal contamination of urban soil in an old industrial city (Shenyang) in Northeast China. Geoderma 192: 50-58.

28. Bogdanovic T, Ujevic I, Sedak M, Listeš E, Šimat V, et al. (2014) As, $\mathrm{Cd}, \mathrm{Hg}$ and $\mathrm{Pb}$ in four edible shellfish species from breeding and harvesting areas along the eastern Adriatic Coast, Croatia. Food Chem 146: 197-203.

29. Li J, Zhiyong HY, Hu Y, Yang H (2013) Potential risk assessment of heavy metals by consuming shellfish collected from Xiamen, China. Environ Sci Pollut Res 20: 2937-2947.

30. Shari Z, Soebarto V, Williamson T (2008) Proposed development of Malaysian sustainable building assessment framework. Proceedings of SENVAR + 2nd ISESEE 2008 International Seminar in Sustainable Environment \& Architecture + International Symposium \& Exhibition in Sustainable Energy \& Environment, Malaysia, 1-3 Dec, Pp: 415-424.

31. Adel M, Dadar M, Fakhri Y, Conti G, Ferrante M (2016) Heavy metal concentration in muscle of pike (Esox lucius Linnaeus, 1758) from Anzali international wetland, southwest of the Caspian Sea and their consumption risk assessment. Toxin Rev 35: 217-223.

32. Saher NU, Kanwal N (2018) Heavy metal contamination and human health risk indices assessment in Shellfish species from Karachi coast, Pakistan. Acad J Food 6: 12-20.

33. FAO/WHO (1999) Expert committee on food additives, Summary and Conclusions, Fifty-third Meeting, Rome.

34. JECFA (Joint Expert Committee on Food Additives) (2003) Summary and conclusions of the $61^{\text {st }}$ meeting of the Joint FAO/WHO Expert Committee on Food Additives (JECFA). JECFA/61/SC, Rome, Italy.

35. Anonymous (2001) Maximum levels for certain contaminants in foodstuffs. Commission Regulation (EC) No 466. Official Journal of the European Communities, pp: 7-11.

36. FAO/WHO (2011) Food standards programme codex committee on contaminants in foods. Fifth Session Codex Alimentarius Commission. The Hague, The Netherlands.

37. FAO/WHO (2010) Summary report of the seventy-third meeting of JECFA. Joint FAO/WHO Expert Committee on Food Additives Geneva.

38. WHO (1996) Trace elements in human nutrition and health. 1. Trace elements - metabolism 2. Trace elements -standards 3. Nutrition 4. Nutritional requirements. NLM Classification: QU 130.

39. WHO (2000) Evaluation of certain food additives and contaminants. Report of the fifty-third of the joint FAO/WHO expert committee on food additives. Technical Report Series No. 896 Geneva.

40. Wang X, Sato T, Xing B, Tao S (2005) Health risk of heavy metals to the general public in Tianjin, China via consumption of vegetables and fish. Sci Total Environ 350: 28-37.

41. Khan S, Lin A, Zhang S, Huc Q, Zhu Y (2008) Accumulation of polycyclic aromatic hydrocarbons and heavy metals in lettuce grown in the soils contaminated with long-term waste water irrigation. J Hazard Mater 152: 506-515.

42. Tsafe Al, Hassan LG, Sahabi DM, Alhassan Y, Bala BM (2012) Evaluation of heavy metals uptake and risk assessment of vegetables grown in Yargalma of Northern Nigeria. J Basic Appl Sci Res 2: 6708-6714.

43. US-EPA IRIS (2006) United States, Environmental protection agency, Integrated Risk Information System.

44. Naveedullah Z, Yu C, Shen H, Duan D, Shen C, et al. (2013) Risk Assessment of heavy metals pollution in agricultural soils of siling reservoir watershed in Zhejiang Province, China. Hindawi Publishing Corporation. BioMed Res Int p: 10.

45. Naveedullah MZ, Chunna Yu Shen H, Duan D, Shen C, et al. (2014) Concentrations and human health risk assessment of selected heavy metals in surface water of the siling reservoir watershed in Zhejiang Province, China. Pol J Environ Stud 23: 801-811. 